\title{
ICT Competencies among School Teachers: A Review of Literature
}

\author{
Wong Ai Yieng, Khadijah Daud \\ Faculty of Education, Universiti Teknologi Malaysia, Malaysia
}

\begin{tabular}{l} 
Article Info \\
\hline Article history: \\
Received Jan 8, 2017 \\
Revised Sep 2, 2017 \\
Accepted Jul 26, 2018 \\
\hline Keywords: \\
Information and \\
Communication Technology \\
School teachers \\
Teacher ICT Competencies
\end{tabular}

\begin{abstract}
A well-prepared abstract enables the reader to identify the basic content of a document quickly and accurately, to determine its relevance to their interests, and thus to decide whether to read the document in its entirety. The Abstract should be informative and completely self-explanatory, provide a clear statement of the problem, the proposed approach or solution, and point out major findings and conclusions. The Abstract should be 100 to 200 words in length. The abstract should be written in the past tense. Standard nomenclature should be used and abbreviations should be avoided. No literature should be cited. The keyword list provides the opportunity to add keywords, used by the indexing and abstracting services, in addition to those already present in the title. Judicious use of keywords may increase the ease with which interested parties can locate our article $(9 \mathrm{pt})$.
\end{abstract}

Copyright $\odot 201 x$ Institute of Advanced Engineering and Science. All rights reserved.

\section{Corresponding Author:}

Wong Ai Yieng,

Faculty of Education, Universiti Teknologi Malaysia, Malaysia.

Email: aiyieng@yahoo.com

\section{INTRODUCTION}

Information and communication technology (ICT) is gaining importance in education since students have emerged as the most active ICT users to have computers and cell phones with internet access [1-5]. Recognizing the importance of ICT in education, the Ministry of Education (MOE) under the Malaysia Education Blueprint 2013-2025 has targeted all teachers should receive training in order to implement ICT in teaching to support student learning [6].

Teachers play the role as a medium between the students with technology, as the driving force in creating an ICT literates society [7]. As educators in schools, it is necessary for teachers to prepare and update all the facts to be presented in subjects using ICT facilities available in schools. The use of ICT in teaching and learning can make a subject as enjoyable event for all students [8-13], even the teacher themselves also gain experience and knowledge while interacting with students.

The level of competence and knowledge of ICT skills among teachers is different in view of digital technology that exists is varied and wide scope [14]. Some educators are quick to master the knowledge and technology skills that exist while there are also educators who are still trying to master the most basic technology such as email, students file management system, internet and office productivity software.

Therefore, it is important for teachers to try to improve ICT knowledge and skills through the National Educational Technology Standards for Teachers 2000 recommended by the International Society for Technology in Education (ISTE). ISTE is an organization representing more than 100,000 educators who support "promoting appropriate uses of information technology to support and improve learning, teaching and administration in education and teacher education" [15]. There are six dimensions in NETS - T, i) technology operations and concepts; ii) planning and designing learning environments and experiences; iii) teaching, learning and the curriculum; iv) assessment and evaluation; v) productivity and professional practice; vi) social, ethical, legal and human issues. 
This six dimensions are important and the standards used to evaluate the skills and knowledge needed by teachers to teach and learn in an increasingly digital global society [16]. Technology operations and concepts is the first dimension for NETS-T. This dimension assesses whether teachers demonstrate basic knowledge, skills and understanding of concepts related to technology. Next, teachers also assessed whether they show continued growth in technology knowledge and skills in line with the current technology. For second dimensions, namely planning and designing learning environments and experiences, teachers are evaluated through their effort in planning and designing effective learning environment to meet the needs of students with diverse abilities.

The third dimensional in NETS-T is teaching, learning and the curriculum. This dimension assesses the efforts of teachers to implement curriculum plans that include methods and strategies with the ultimate goal of using technology to maximize student learning. For fourth dimensions is assessment and evaluation, teachers need to integrate technology strategy to diversify the effective measurement and evaluation. Therefore, teachers were assessed whether they apply the technology to assess student learning on a subject, use technology resources to collect and analyze data. Productivity and professional practice is the fifth dimensions. This dimension emphasizes teachers use technology to enhance their productivity and professional practice. So, teachers assessed whether applying technology to improve the continuous professional and use technology to communicate and collaborate with colleagues, parents and the community to improve student learning.

Dimension six and last dimension is social, ethical, legal and human issues. This dimension emphasizes the teachers need to understand the social, legal and ethical issues that arise in the school due to the use of technology in schools. Therefore, teachers should serve as role models to tell about the legal and ethical practice related to technology use. They should promote the use of technology in safe and healthy ways. Based on standards in NETS-T, this paper will examine the success and the lack of teachers in ICT under six dimensional NETS-T. The success of teachers in satisfying the needs of NETS-T is an encouraging boost to the educators. However, any shortfall must be made as awareness to teachers to improve themselves to be regarded as effective educators today.

\section{SUCCESS TEACHERS IN ICT UNDER SIX DIMENSIONAL NETS - T}

\subsection{Technology Operations and Concepts}

The first dimension in NETS - $\mathrm{T}$ is technology operations and concepts. This dimension is concerned about the attitudes, skills and knowledge technology. Researchers like [13], [17], [11], [18] found that many educators have mastered the basic skills in the use of technology. Majority of teachers believed to be capable of producing relevant documents using ICT applications, process and get information through the Internet, using multimedia in the process of teaching and learning and carry out basic operations in handling ICT tools. In this nano technology world, it is becoming a necessity and an obligation for teachers to equip themselves with knowledge and skills in the latest ICT in line with the current changes [7].

\subsection{Planning and Designing Learning Environments and Experiences}

This dimension requires the efforts of various parties to design a learning environment that enables students to master ICT skills consistent with the educational goals. The issue of the digital divide between rural and urban areas attract the government attention through the implementation of the telecenter (TC) and the village wifi [19]. In addition, various programs such as the Village Internet Program, Village Portal, Computer Ownership Program and Mobile Internet Program also launched as joint effort between the government and private agencies in order to achieve smart partnerships [20]. All these efforts have the same goal that every individual can engage in multimedia development and reduce the digital gap between urban and rural areas.

\subsection{Teaching, Learning and the Curriculum}

To perform the task as educators, teacher need to have the knowledge and skills to use the computer, trying to use the internet, email and integrate technology in the classroom [21]. Therefore, all teachers are trained to efficiently use the Frog VLE (virtual learning environment) by 2016 based on the learning environment of creativity and innovation provided by the Ministry of Education as well as digital equipment like tablet or smartphone that is available to teachers and students (Utusan Malaysia, May 28, 2013). Indeed, the integration of ICT in the teaching and learning is required in view of the various advantages and benefits can be obtained [18]. 


\subsection{Assessment and Evaluation}

This dimension is no stranger to the teachers as project assessment and evaluation is an obligatory task that must be implemented by all teachers [18]. In fact, the study by researchers like [18, 11] also confirmed that teachers frequently and often provide test questions and exams, test scores and examination record and analyze the results of tests and examinations with the use of ICT. The performance data of these students is important for teachers to plan for the next lesson. The Johor states are example that can be learned with success boost of education performance from the bottom five places into the top group within just five years [6]. With the implementation of the reporting system on-line (headcount), Johor teachers managed to achieve success. Discussions about why success or failure of students to achieve the set targets will be made jointly between headmasters and teachers at the school level. Besides that, activities such as enrichment, strengthening and recovery will be followed by additional classes conducted after school hours. This impressive success can indeed serve as a role model for all school staff who want success.

\subsection{Productivity and Professional Practice}

In this dimension, teachers have an obligation to up-skill themselves because it is equivalent to an increase in their productivity [11]. Therefore, teachers should take the opportunity and initiative to take a course or training ICT professional development organized by the school, the Education Technology Division of the State and the State Education Department to enhance the capability and capacity of their ICT [11], [22-24]. Teachers must have the self-awareness necessary to improve the efficiency and ICT skills. It is the duty of educators to educate the younger generation technology savvy generation to contribute to national development.

\subsection{Social, Ethical, Legal and Human Issues}

This dimension is a dimension that should not be ignored by a teacher. As obtained in the study Mohd Jamil [11], teachers taught their students about the dangers of polluting the dignity of a person on the internet. Teachers also often remind students about the misuse of ICT. Teachers also insist on the students to adopt a healthy and safe life while using the internet. It is important for teachers to produce a healthy environment for primary school students to use their visual, hearing and kinesthetic senses to learn technology in education. The students will also be motivated because of the opportunity to be exposed to technology from an early age and use their senses involved in technology [21]. It will guide students in learning throughout their lives.

\section{SHORTAGE OF TEACHERS IN ICT UNDER SIX DIMENSIONAL NETS - T}

\subsection{Technology Operations and Concepts}

In this dimension, teachers are criticized for not comfortable with computers [25-27] and is still not ready to support the use of technology in schools [28]. Researchers like [29-31] found that teachers have the misconception that the internet is the addition of a new workload and they are less skilled in using this application. Besides that, [28], [32,33] also notice teachers especially veteran teachers do not like to change and are not willing to learn and improve skills in using ICT and internet access. This adverse effect on student achievement because the teachers are not able to use technology effectively in schools. Similarly [20, 34] also revealed that teachers do not have the level of knowledge about the latest ICT equipment. This prevents the development and implementation of ICT in the school culture.

\subsection{Planning and Designing Learning Environments and Experiences}

Challenges to be overcome by the teachers in this dimension is the issue of the digital divide between rural and urban areas and the issue of teachers' planning in terms of time. Siti [35], Surendran \& Norazlinda [36] and Hazura [19] found that the use of computers and ICT among teachers in rural areas is lower than the city. The significant difference is not due to the level of literacy among teachers working in schools of the city or rural areas but the lack of facilities and the ability of students is lower in rural areas is the main stumbling block to the acceptance software courseware [19, 28]. This is supported by [37] which states ICT penetration is inherent inequalities between the urban and rural areas. In addition, teachers also reported to have constraints in terms of time for using ICT in the classroom [38], [8], [39], [33]. Some teachers feels that it's a waste of time to install ICT equipment for the implementation of the teaching and learning in the classroom [8], [33], [39]. There are also teachers said that the use of technologies are inconvenience as they need to find time to learn the new skills required to teach with technology [38], [4042]. There were also teachers give opinions using technology to encourage them to use more time to address student misconduct rather than the use of ICT to launch the process of the teaching and learning in the classroom [42-44], This prevents the development of ICT in schools. 


\subsection{Teaching, Learning and the Curriculum}

In this dimension, the teachers received a reprimand from various quarters for allegedly not integrate ICT in teaching and learning [45], [46], [39], [21], [11], [47], [38], [48], [49], [23], [50], [6], [8], [51]. Some researchers criticized the teachers have a high level of ICT skills but do not integrate technology in their teaching and learning [51], [6], [50], [8], [47]. This can be proven through studies [52] who found the equipment ICT is complete in schools but teachers still difficult to integrate ICT in teaching and learning. Similary, Kazi [47] also revealed that teachers use ICT facilities not for teaching and learning but for administrative purposes and to have fun like playing computer games. Besides that, there were also teachers said to be uncomfortable with technology and people expressed suspicion about whether they have ability to integrate technology into teaching and learning [45], [49], [7]. This is very detrimental to students, schools and countries in produce caliber human capital in various fields.

\subsection{Assessment and Evaluation}

For this dimension, teachers appear less in assessing learning outcomes of students in technology [18]. In other words, teachers are less in presenting students performance in data like graphs for analysis and subsequent postmortem. This situation can be attributed to poor use of graphics among teachers and can be confirmed by the findings [53], [10], [50], [9]. Leong [18] also added that teachers make workload as the reason for the lack of student performance data presented in graphical form.

\subsection{Productivity and Professional Practice}

In the dimension of productivity and professional practices, inadequate professional development available is a major hurdle for teachers to integrate ICT in teaching and learning [54], [53], [20], [6]. Flanagan \& Jacobsen [54] and Norazlina [35] revealed that many teachers do not have the opportunity to engage in professional development to learn ICT skills required by them. For the teachers who took the opportunity and the initiative to enroll in training or courses in ICT, the skills they learned most is the skill of computer applications rather than strategic integration technologies is needed by them for the integration of ICT in the teaching and learning [51], [23], [21], [55]. At the same time, teachers also face the problem of lack of access to computers at school for drill and practice what they have learned. It is the common memory of individuals will quickly forget ICT knowledge learned if teachers are not given the opportunity to apply what they are learning in ICT professional development training. So, this prevents the development of ICT skills of individuals and in turn affect the development of ICT in schools.

\subsection{Social, Ethical, Legal and Human Issues}

This dimension should receive serious attention from the teachers as there are a growing number of unethical behaviour in ICT . Lau and Yuen [56], Hu et al. [57] and Xu et al. [58] found the youth love stuck with three of unethical behaviour, namely i) unauthorized acts such as computer hacking and software piracy ; ii) internet stickiness and iii) plagiarism . Similarly, Lau and Yuen [56], Gunter et al. [59] and Teston [60] also confirmed that internet piracy rate is common practice in youth culture today.

\section{CONCLUSION}

As educators in the 21st century, teachers need to internalize this profession in line with the changing times. Highlights of this study can serve as a guide or foundation to improve weaknesses. Teachers must put in energy and expertise to integrate ICT in teaching and learning in order to polish the talent and strengthening the potential of students to be successful in all fields of endeavor.

\section{Acknowledgement}

This article is part of a study of my PHD thesis entitled Headmaster Technology Leadership and Teacher Integration Technology that carried out in Johor, Malaysia.

\section{References}

[1] Hakoama, M., \& Hakoyama, S. "The impact of cell phone use on social networking and development among college students". The American Association of Behavioral and Social Sciences Journal. 15, 1-20, 2011.

[2] Smith, A. " $17 \%$ of cell phone owners do most of their online browsing on their phone, rather than a computer or other device". 2012. Retrieved from http://pewrinternet.org/Reports/2012/Cell- Internet-Use-2012.aspx.

[3] Wentworth, D.K. \& Middleton, J,H. "Technology use and academic performance". in Computer \& Education, 2014, 78: 306-311. 
[4] Smith, S. D., \& Caruso, J. B. “The ECAR study of undergraduate students and information technology”. 2010. Retrieved from http//www.educause.edu/Resources/ECARStudyofUndergraduateStuden/217333.

[5] 5. Smith, A., Rainie, L., \& Zickhur, K. "College students and technology". 2011. Retrieved from http: www.pewinternet.org/Reports/2011/College-students-andtechnology.aspx.

[6] Malaysia's Ministry of Education (MOE). Malaysian Education Development Plan 2013-2025 (Preschool to PostSecondary Education). Putrajaya: Ministry of Education. 2013.

[7] Zuraidah, Abdullah, Julia Bujang. The phobia of computers among elementary school teachers: a case study. 1st International Malaysian Educational Technology Convention. PP 390-396, 2007.

[8] Muhammad Akbar Zahidi. "Implementation Use of ICT in Teaching English in primary schools". Seminar Hasil Penyelidikan Sektor Pengajian Tinggi ke 3. Putrajaya: Malaysia's Ministry of Education. 2013.

[9] Rahmad Sukor Ab Samad, Kazi Enamul Houque, Ma Yu, Abdul Jalil Othman, Mohamed Iskandar Rahmad Sukor \& Megat Ahmad Kamaluddin Megat Daud. "Uses of ICT in English Teaching in Primary Schools in Wei Nan City, China”. International Journal of Learning \& Development, 3(4):78-86. 2013.

[10] Christina Andin @ Nur Qistina Abdullah. "The Use of Information and Communication Technology (ICT) Among Primary School Teachers”. Unpublished Degree Project Paper. Johor: Universiti Teknologi Malaysia. 2009.

[11] Mohd Jamil Saleh. "Principal Technology Leadership in a Smart School in Kota Tinggi, Johor". Unpublished Master Project Paper. Kuala Lumpur: Universiti Malaya, 2011.

[12] Lukman Dinyati. "Perception of Islamic Education Teachers on the Use of ICT for teaching and learning at the Primary School in Kluang". A report of Bachelor of Education (Education Management). Johor: Universiti Teknologi Malaysia. 2008.

[13] Rosnaini Mahmud, Mohd Arif Ismail, Paridon Sahid \& Zainuddin Yazid. "ICT Integration level Among Teachers Hulu Langat, Selangor". 1st International Malaysian Educational Technology Convention. 2007. PP 1056-1071.

[14] McLeod, S., \& Richardson, J. W. "Supporting effective technology integration and implementation". In $M$. Militello and J. I. Friend (Eds.), Principal 2.0: Technology and educational leadership. Charlotte, NC: Information Age Publishing. 2013.

[15] Brooks-Young, S. "Making technology standards work for you. Eugene", WA: International Society for Technology in Education. 2002.

[16] ISTE (2014). National educational technology standards for teachers. Retrieved from http://www.iste.org/standards/standards-for-teachers

[17] Moktar Johar. Technology leadership and Teacher Competency in ICT at Islamic schools in the District of Kuching, Sarawak. Unpublished Master Project Paper. Kuala Lumpur: Universiti Malaya. 2011.

[18] Leong, M.W. "Principal's Technology Leadership and Teacher's Information and Communication Technology (ICT) application phase in Secondary schools at Seremban". Unpublished Master Project Paper. Kuala Lumpur: Universiti Malaya. 2010.

[19] Hazura Mohamed, Hairulliza Mohamad Judi, Siti Fadzilah M. Noor \& Zawiyah M. Yusof. Digital and Education Divide in Rural Areas: The Information and Communication Technology Literacy level among Students. Journal of Information Technology and Multimedia Asia-Pacific. Vol.1 No. 2, December 2012 In Bridging Digital Divide: A Study on ICT Literacy among Students in Malaysia Rural Areas. Australia Journal of Basic and Applied Sciences 2012, 6(7):39-45.

[20] Hairulanuar Abd Samat. Management of Information and Communication Technology at the Sekolah Kebangsaan and Sekolah Rendah Jenis Kebangsaan Cina in Muar, Johor. Unpublished Master Project Paper. Johor: Universiti Teknologi Malaysia. 2013.

[21] Grey Bowen, J. E. A study of technology Leadership among elementary public school principals in Miami-Dade County. Thesis Phd: St. Thomas University. 2010.

[22] Waxman, H.C., Boriack, A. W., Lee, Y. H. \& MacNeil, A. Principals' "Perceptions of the Importance of Technology in Schools". Contemporary Educational Technology, 4(3): 187-196. 2013.

[23] Draper, K. L. An examination of the relationship between principal technology leadership and technology integration in urban schools. Thesis PHD: University of Oklahoma. 2013.

[24] Redish, T., \& Chan, T. C. Technology leadership: Aspiring administrators' perceptions of their leadership preparation program. Electronic Journal for the Integration of Technology in Education, 6: 123-139. 2007.

[25] Bohlin, R. M. Avoiding Computer Avoidance. 2002 Retrieved 2/6/2014 from http://itforum.coe.uga.edu/paper35/paper35.html

[26] Cradler, J. \& Cradler, R. Improving California Schools: Meeting the Challenge with Technology. Atlanta, Georgia: NetSchools Transforming Education. 2001.

[27] Roslee Talip, Mohd Yusof Abdullah, Baharom Mohamad, Abdul Said Ambotang, Shukri Zain \& Muhamad Suhaimi Taat. Teachers as agents of transformation in curriculum innovation. Utusan Borneo. B4. 2012

[28] Richardson, J.W. \& McLeod, S. Technology Leadership in Native American Schools. Journal of Research in Rural Education, 2011; 26(7). Retrieved from http://jrre.psu.edu/articles/267.pdf.

[29] Nothirp A/P Prak Jun. Internet Usage among Secondary Schools Teachers in Kluang District. Unpublished Master Project Paper. Kuala Lumpur: Universiti Malaya. 2008.

[30] Rosnaini Mahmud. The willingness of Information and Communications Technology in Basic Education (MKP) Among Secondary School Teachers. Thesis Phd. Selangor: Universiti Kebangsaan Malaysia. 2006.

[31] Norizan Abdul Razak. Computer competency of in-service ESL teachers in Malaysian secondary schools. Thesis Phd. Selangor: Universiti Kebangsaan Malaysia. 2003. 
[32] Tay, S. H. Shirley, Nety Irawadty \& Seng Kok Leong. Collaborative Leadership towards ICT Culture Preservation in SMK Bandaraya Kota Kinabalu. ICT Colloquium on Educational Management and Leadership in 2013. Institut Aminuddin Baki: Malaysia's Ministry of Education. 2013.

[33] Hilmi Hassan. Computer Management in Teaching and Learning: A Study in A Rural School at Gerik District, Perak. Unpublished Master Project Paper. Kuala Lumpur: Universiti Malaya. 2006.

[34] Franklin, C. Factors that influence elementary teachers' use of computers. Journal of Technology and Teacher Education, 2007; 15(2): 267-293.

[35] Siti Norazlina Kamisan. Barriers to Use Computers and ICT in Teaching and Learning (T \& L) Among Secondary School Teachers in Rural in Kulai Jaya, Johor. Unpublished Degree 2008.

[36] Surendran Sankaran \& Norazlinda Saad. Technology Reception: The Role of School Location As the Moderator. In: Proceedings of the Seminar Council of Deans of Education IPTA 2012, 6 -9 Oktober 2012, Johor: The Zon Regency Hotel.

[37] Salman, A. \& Hasim, M.S. Internet Usage in a Malaysian Sub-Urban Community: A Study of Diffusion of ICT Innovation. The Innovation Journal: The Public Sector Innovation Journal, 2011; 16(2. http://www. innovation.cc/case

[38] Kopcha, T.J. Teachers' perceptions of the barriers to technology integration and practices with technology under situated professional development. Computers \& Education. 2012; 59 (2012): 1109-1121.

[39] Rosnaini Mahmud, Mohd Arif Hj. Ismail \& Jalalludin Ibrahim. The level of skills and integration of ICT among teachers in Smart School. Jurnal Teknologi Pendidikan Malaysia, 2011, 1(1): 5-13.

[40] Al-Senaidi, S., Lin, L., \& Poirot, J. Barriers to adopting technology for teaching and learning in Oman. Computers \& Education, 2009; 53(3): 575-590.

[41] Clark, K. Practices for the use of technology in high schools: a Delphi study. Journal of Technology and Teacher Education, 2006; 14(3): 481-499.

[42] Lim, C. P., \& Khine, M. Managing teachers' barriers to ICT integration in Singapore schools. Journal of Technology and Teacher Education, 2006; 14(1): 97-125.

[43] Bauer, J., \& Kenton, J. Toward technology integration in the schools: why it isn't happening. Journal of Technology and Teacher Education, 2005; 13(4): 519-546.

[44] Wachira, P., \& Keengwe, J. Technology integration barriers: urban school mathematics teachers perspectives. Journal of Science Education and Technology, 2010; 20(1): 17-25.

[45] Leonard, L. J. \& Leonard, P. E. Leadership for Technology Integration: Computing the Reality. The Alberta Journal of Educational Research, 2006; 52(4): 212-224.

[46] Sabri Ahmad. Teaching and Learning Mathematics using Information and Communication Technology (ICT) In Sabri Ahmad, Tengku Zawani Tengku Zainal, Aziz Omar: Issues in Mathematics Education. Kuala Lumpur: Utusan Publication \& Distributors Sdn. Bhd. 2006.

[47] Kazi Enamul Hoque, Ahmad Zabidi Abdul Razak, Mosa. Fatema Zohora. The use of ICT among teachers and headmaster in Malaysia. International Journal of Academic Research in Progressive Education and Development. 2012; 1(4): 17- 34.

[48] Padron, Y. N., Waxman, H. C., Lee, Y. H., Linn, M. F., \& Michko, G. Classroom observations of teaching and learning with technology in urban elementary school mathematics classrooms serving English language learners. International Journal of Instructional Media, 2012; 39(1): 45-54.

[49] Cakir, R. Technology Integration and Technology Leadership in Schools as Learning Organizations. The Turkish Online Journal of Educational Technology. 2012; 11 (4):273-282.

[50] Ghamrawi, N. The Relationship between the Leadership Styles of Lebanese Public School Principals and Their Attitudes towards ICT versus the Level of ICT Use by Their Teachers. Open Journal of Leadership, 2013; 2(1): 11-20.

[51] Fisher, D. M. \& Waller, L. R. The 21st Century Principal: A Study of Technology Leadership and Technology Integration in Texas K-12 Schools. The Global ELearning Journal, Volume 2, Number 4, 2013.

[52] Hartman, J. L., Dziuban, C., \& Brophy-Ellison, J. Faculty 2.0. Educause Review, 2007; 42(5): 62-76.

[53] Mona Masood \& Nor Azilah Ngah. Training needs in ICT teaching materials among teachers in secondary schools in Malaysia. Ist International Malaysian Education technology Convention, 2007; 631-637.

[54] Flanagan, L. \& Jacobsen, M. Technology leadership for the twenty-first century principal. Journal of Educational Administration, 2003; 41(2): 124-142.

[55] Cummings, C. D. A study of technology leadership among elementary principals in a suburban Texas independent school district (Doctoral dissertation). Available from ProQuest Dissertations and Theses database. (UMI No. 3510141). 2012.

[56] Lau, W.F. \& Yuen, H.K. Internet ethics of adolescents: Understanding demographic differences. Computers \& Education, 2014: 72;378-385.

[57] Hu, Q., Xu, Z., \& Yayla, A. A. Why college students commit computer hacks: insights from a cross culture analysis. Paper presented at The Pacific Asia Conference on Information Systems, Jeju Island, Korea. 2013.

[58] Xu, Z., Hu, Q., \& Zhang, C. Why do computer talents become computer hackers? Communications of the ACM, 2013; 56(4): 64-74.

[59] Gunter, W. D., Higgins, G. E., \& Gealt, R. E. Pirating youth: examining the correlates of digital music piracy among adolescents. International Journal of Cyber Criminology, 2010; 4(1\&2): 657-671.

[60] Teston, G. Software piracy among technology education students: investigating property rights in a culture of innovation. Journal of Technology Education, 2008; 20(1): 66- 78. 